\title{
Pelleting on the Nutritional Quality of Broiler Feeds
}

\author{
Isabel Cristina Vaccari Mores
}

Master in Animal Production - Federal Goiano Institute, Department of Animal Husbandry, Rio Verde Campus, South Goiana Highway, Km 01, no, Rural Area, PO Box 66, Zip Code 75901-970 Rio Verde, GO, Brazil. Email: isabel@lirabel.com.br

Keysuke Muramatsu

PhD in Veterinary Sciences from the Federal University of Paraná - Rua dos Staff, 1540 Juvevê, Curitiba - PR - Brazil | ZIP Code: 80035-050 | Phone: (041) 3350-5861 E-mail: ppgz@ufpr.br

Alex Maiorka

$\mathrm{PhD}$ in Animal Science from Paulista State University Júlio de Mesquita Filho Postgraduate Program in Animal Science - Employee Street, 1540 - Juvevê, Curitiba - PR - Brazil | ZIP Code: 80035-050 | Phone: (041) 3350-5861 E-mail: ppgz@ufpr.br

\section{Uislei Antonio Dias Orlando}

$\mathrm{PhD}$ in Animal Science from the Federal University of Viçosa - Avenida PH. Rolfs, no University Campus Viçosa - MG TEL: (31) 3612-4616 E-mail : dzo@ufv.br ZIP Code: 36570-900

\section{Julia Marixara Sousa da Silva (Corresponding Author)}

Master's degree in Animal Science by the Federal Goiano Institute - Rio Verde Campus Federal Goiano Institute - Rio Verde Campus Sul Goiana Highway - km 1 - Rio Verde Rural Zone - GO - Brazil ZIP Code: 75.901-970. E-mail:marixara13@yahoo.com

\section{Lorrayne Moraes de Paulo}

Zootechnist at the Federal Institute of Goiano; Department of Animal Science. Rio Verde-GO Brazil. Federal Goiano Institute- Rio Verde Campus South Goiana Highway - km 1 - Rio Verde Rural Zone - GO - Brazil ZIP Code: 75.901-970.

E-mail: lorraynemoraesrv@gmail.com 
Alison Batista Vieira Silva Gouveia

Master's degree in Animal Science by the Federal Goiano Institute - Rio Verde Campus Federal Goiano Institute - Rio Verde Campus Sul Goiana Highway - km 1 - Rio Verde Rural Zone - GO - Brazil ZIP Code: 75.901-970. E-mail: alisonmestre28@ gmail.com

\begin{abstract}
Weslane Justina da Silva
Master's degree in Animal Science by the Federal Goiano Institute - Rio Verde Campus Federal Goiano Institute - Rio Verde Campus Sul Goiana Highway - km 1 - Rio Verde Rural Zone - GO - Brazil ZIP Code: 75.901-970. E-mail: weslanejds@ gmail.com
\end{abstract}

\title{
Jiovanna Gonçalves Sousa
}

Zootechnist at the Federal Institute of Goiano; Department of Animal Science. Rio Verde-GO Brazil. Federal Goiano Institute Rio Verde Campus South Goiana Highway - km 1 - Rio Verde Rural Zone - GO - Brazil ZIP Code: 75.901-970. E-mail: jiovannaji@gmail.com

\section{Cíntia Silva Minafra e Rezende}

$\mathrm{PhD}$ in Animal Science from the Federal University of Goiás - UFG, Federal University of Goiânia Goiânia Highway, km 8 s / n Campus - Samambaia, Goiânia - GO, 74001-970 Goiânia-GO, Brazil. E-mail: cintia.minafra@ufg.br

\section{Cibele Silva Minafra}

$\mathrm{PhD}$ in Biochemistry from the Federal University of Viçosa - Professor at the Goiano Federal Institute; Department of Zooetnia. Rio Verde - GO Brazil.

Email: cibele.minafra@ifgoiano.edu.br

Received: Dec. 18, 2019 Accepted: Jan. 15, 2020 Published: Feb. 26, 2020

doi:10.5296/jas.v8i3.16072～URL: https://doi.org/10.5296/jas.v8i3.16072

\begin{abstract}
In the pelleting process, mash feed passes through a conditioner were it is exposed to steam under high pressure and pushed through the die to form pellets. To determine the effect of adding different amounts of water and different thermal processing parameters on the pellet conversion percentage, pellet durability index (PDI) and solubility of protein in $\mathrm{KOH}$ of broiler feed. The processing factors were combined in a $4 \times 2$ factorial scheme: four moisture
\end{abstract}


addition levels $(0 \% ; 0.7 \% ; 1.4 \% ; 2.1 \%)$, and two thermal processes (conditioning-pelleting or conditioning-expanding-pelleting). Eight samples of each treatment were collected to evaluate quality parameters. The feed used in this study was a typical corn-soybean broiler diet processed in a commercial feed mill. The pellet conversion percentage and PDI responded linearly and positively in the range of 0 to $2.1 \%$ moisture addition. Positive and linear equations relating moisture addition in the conditioner with pellet conversion percentage and PDI were obtained $(\mathrm{p}<0.001)$. Expansion improved PDI and pellet percentage respectively by $18 \%$ and $21 \%$ when compared to simple conditioning-pelleting feed processing. However, an adverse effect on protein quality was observed when higher processing temperature was used. No particle size effect was observed for conditioned-expanded-pelleted feed. Medium particle size resulted in better PDI and higher pellet conversion percentage $(\mathrm{p}<0.001)$ compared to coarse grinding ( $\%$ pellets $-66.97 \%$ versus $64.96 \%$; PDI $-77.30 \%$ versus $66.10 \%$ ).

Keywords: coarse, expanded, feed mill, medium, pelleted

\section{Introduction}

In the pelleting process, mash feed passes through a conditioner were it is exposed to steam under high pressure and pushed through the die to form pellets. Since pelleting is a costly stage in a feed mill, it is important to achieve the maximum effectiveness of this process. This means a maximum amount of unbroken pellets at the mill and sufficient resistance to withstand typical handling during transport to farms (Melo et al., 2016).

Pellet quality can be expressed as percentage of pellets produced and the pellet durability index (PDI, a measure of pellet resistance against fragmentation and impact forces). Franke and Rey (2006) and Mendez et al. (2008) reported that fracture points may occur when particles bigger than $1.00-1.50 \mathrm{~mm}$ are incorporated into the pellet structure. The use of annular gap expanders in feed mills also has a positive effect on PDI (Vukmirovic et al., 2017). In some feed mills, a certain amount of water is added in the mixer in order to increase the moisture content of mash feed prior to conditioning (Boemo et al., 2016). Attar et al. (2017) reported that the addition of $2.5 \%$ and $5.0 \%$ water in the mixer prior to pelleting increased the PDI. Kanmani et al. (2018) observed improvements on pellet quality when $2 \%$ and $4 \%$ tap water were added in the mixer.

In addition, parameters such as starch gelatinization and protein solubility can be monitored in order to check the effect of thermal processing on the feed ingredients. Muramatsu et al. (2013) evaluated the effect of an annular gap expander at $130-136^{\circ} \mathrm{C}$ on corn and soybean meal and observed that $29.67 \%$ and $19.19 \%$ of the starch contents were gelatinized. The high temperature, pressure and shearing forces present during the heat treatment of the feed can lead to formation cross-links in the protein structure that cannot be degraded by enzymatic activities (Röhe et al., 2014; Prestlokken \& Fôrutvikling, 2012). Protein solubility in 0.2\% potassium hydroxide solution $(\mathrm{KOH})$ is a useful tool to measure protein quality of heat processed feed ingredients.

The objective of the experiment reported here was to determine the effect of feed particle size, 


\section{Macrothink Institute ${ }^{\text {TM }}$}

different moisture addition to the mash feed in the conditioner and two thermal processes (conditioning-pelleting or conditioning-expanding-pelleting) on the pellet quality and protein solubility of corn-soybean broiler feeds.

\section{Material and Methods}

Feed processing. An experimental feed containing 2.5\% added fat was formulated (Table 1) in order to evaluate the effects of particle size, moisture addition and processing parameters pellet quality and protein solubility. A commercial feed mill, located in Rio Grande do Sul state, Brazil, was used to produce the experimental feeds.

The ingredients were first passed through a $5.0 \mathrm{~mm}$ mesh sieve, and all coarse ingredients (whole corn kernels and coarse soybean meal fragments) were ground in a hammer mill (Buhler vertical hammer mill with 16 hammers - 10 tons/hour output/unit x 6 units) to achieve medium and coarse particle size of the final feed. The different particle sizes were attained by changing the hammer tip speed, since the hammer mill was equipped with a variable hammer rotation control $(3600 \mathrm{rpm}$ for medium size grinding and $1800 \mathrm{rpm}$ for coarse size grinding). All the feed components were blended in a paddle mixer (Buhler DFML $8000 \mathrm{~L}, 6000 \mathrm{~kg}$ capacity). The mixing time was divided in three phases: dry mixing (45 seconds), liquid addition (60-90 seconds) and wet mixing (25 seconds).

Table 1. Composition of the experimental feeds

Ingredients

Quantity (g/Kg)

Cornmeal

662.00

Soybean meal

239.00

Poultry byproducts meal

40.00

Soybean oil

Feather meal

10.00

Limestone

Liquid 1-lysine (50\%)

Salt

Monobicalcium phosphate

DL-methionine 
$\begin{array}{ll}\text { Vitamin }_{\text {premix }}{ }^{\mathrm{a}} & 1.00\end{array}$

$\begin{array}{lr}\text { Betaine- } \mathrm{HCl} & 0.90\end{array}$

$\begin{array}{ll}\text { Trace mineral premix } & 0.85\end{array}$

$\begin{array}{lr}\text { Liquid choline chloride (75\%) } & 0.70\end{array}$

$\begin{array}{lr}\text { L- threonine } & 0.60\end{array}$

$\begin{array}{ll}\text { Liquid phytase } & 0.05\end{array}$

Total

Calcium \%

$\mathrm{EM} \mathrm{kcal} / \mathrm{kg}$

Available Phosphor \%

Lysine Dig. birds \%

Met + Cist Dig. birds \%

Methionine Dig. birds \%

Crude protein $\%$

Sodium \%

${ }^{\text {a }}$ Supplied per kg of complete diet: $7000 \mathrm{IU}$ of vitamin A, $2000 \mathrm{IU}$ of vitamin D3, $25 \mathrm{IU}$ of vitamin E, $2.0 \mathrm{mg}$ of menadione, $4.0 \mathrm{mg}$ of riboflavin, $25.0 \mathrm{mg}$ of niacin, $12.0 \mathrm{mg}$ of d-pantothenic acid, $4.0 \mathrm{mg}$ of vitamin pyridoxine, $0.01 \mathrm{mg}$ of vitamin B12, $1.0 \mathrm{mg}$ of folic acid and $0.08 \mathrm{mg}$ of biotin. ${ }^{\mathrm{b} S u p p l i e d}$ per $\mathrm{kg}$ of complete diet: $10 \mathrm{mg}$ of copper as copper sulfate, $1 \mathrm{mg}$ of iodine as calcium iodate, $60 \mathrm{mg}$ of iron as ferrous sulfate, $70 \mathrm{mg}$ of manganese as manganese sulfate, $0.3 \mathrm{mg}$ of selenium as sodium selenite, and $70 \mathrm{mg}$ of zinc as zinc sulfate. 
The feed was steam-conditioned for 15 seconds at $80-82^{\circ} \mathrm{C}$ under steam pressure of $1.5-2.0$ bar. Then the feed was directed either to an expander (Kahl expander, model 38.2, 40 tons/hour output, with average feed retention time of 5 seconds, annular gap pressure of $11-13 \mathrm{kwatt} / \mathrm{ton} / \mathrm{hour}, 2,000 \mathrm{~mm}$ length, $400 \mathrm{~mm}$ width and $600 \mathrm{hp}$ ) or directly to the pellet mill (Buhler model DPAS, 30 tons/hour output, die specifications: $660 \mathrm{~mm}$ diameter, die holes with $60 \mathrm{~mm}$ depth and $4.5 \mathrm{~mm}$ diameter and with no relief, $350 \mathrm{hp}$ and $1.0 \mathrm{~mm}$ gap between die and roll). The moisture addition levels in the conditioner were controlled by means of a water apportioning system (Kahl WD-GLI15, water temperature $60{ }^{\circ} \mathrm{C}$ and water pressure 3-6 bar). After the feed passed through the press, it was cooled in a Buhler model DFKG 30 cooler with cooling capacity of 30 tons of feed/hour.

Sampling. In order to evaluate the effect of different moisture addition levels $(0 \% 0.7 \% ; 1.4 \%$ and $2.1 \%$ water addition), thermal processing (pelleted $\mathrm{x}$ expanded-pelleted) and particle size (medium and coarse), four batches of four tons of feed (total of 16 tons) were mixed in sequence for each particle size ( 2 x 16 tons). The feed was tested for particle size by sampling the mash feed delivered by the mixer. Three samples of approximately 500 grams (composite sample) were collected for particle size determination. The particles sizes were determined according to the method referenced by the American Society of Agricultural and Biological Engineers (ASABE, 2006). The average result of the three samples was used to define the average particle size of the four batches.

The treatments were organized to fit the different moisture addition levels in each thermal process. The moisture addition in the conditioner was done from the lowest to highest level initially for pelleted feed ingredients. For each moisture addition level, 8 samples of approximately $500 \mathrm{~g}$ were collected directly from the discharge of the pellet press. These samples were cooled in room temperature 24 hours before they were submitted to physical and chemical analysis. Sample collections were conducted after the conditioner-expander-pellet press achieved stable operating parameters (production rate, temperature and energy consumption). Once all the moisture addition was tested for pelleted diets, the different moisture levels were tested for expanded-pelleted feed following the same procedures described previously. Finally, all these procedures were repeated for coarse and medium particle size.

Feed Analysis. The feed from different treatments was analyzed for the following physical and chemical parameters: Pellet durability index (PDI): determined according to Method S269.4 from ASAE Standards (Mina-Boac et al. 2006); Percentage of pellets: 200 grams of feed were passed through a sieve with $3.0 \mathrm{~mm}$ round holes and the portion of feed retained in this screen was considered to be pellets; Protein solubility in $\mathrm{KOH}$ : determined according to the method described by Parsons et al. (1991); Moisture content: determined according to Method 930.15, referenced by the Association of Official Analytical Chemists International (1998).

Statistical analysis. The general linear model procedures of Statgraphics Centurion XVI (Stat Point Technologies, Inc) were used to analyze the data. The statistical model included the replicates, particle size, type of heat treatment and level of moisture addition: Yijkl $=\mu+\mathrm{MAi}$ 
$+\mathrm{HTj}+$ PSk + Eijkl Where: Yijkl = observation, $\mu=$ population mean, MAi $=$ moisture addition effect ( $\mathrm{I}=0$ to $2.1 \%), \mathrm{HTj}=$ heat treatment effect $(\mathrm{j}=$ pelleted or expanded-pelleted $)$, PSk = particle size effect $(\mathrm{k}=$ medium or coarse particle size $)$ and $\varepsilon i j \mathrm{kl}=$ residual error.

\section{Result and Discussion}

Coarser particle size impaired the pellet conversion percentage in comparison to medium particle size $(\mathrm{p}<0.001)$ (Table 2).

The feed particle sizes achieved in the tests were respectively 988 microns for coarse grinding and 656 microns for medium grinding. The average moisture content of mash feed samples prior to conditioning was $12.02 \pm 0.62 \%$, and for the pelleted-expanded feed samples taken after cooling was $12.52 \pm 0.71 \%$.

Table 2. Effect of heat treatment (HT), particle size (PS) and moisture addition (MA) on pellet durability index, pellet percentage and feed protein solubility $(\mathrm{KOH})$

Factors Pellet durability index Pellets percentage Protein solubility $(\mathrm{KOH})$

Moisture addition

\begin{tabular}{lccc}
\hline $0.0 \% \mathrm{H}_{2} \mathrm{O}$ addition & 69.35 & 76.93 & 69.19 \\
$0.7 \% \mathrm{H}_{2} \mathrm{O}$ addition & 77.22 & 78.63 & 69.31 \\
$1.4 \% \mathrm{H}_{2} \mathrm{O}$ addition & 78.83 & 81.88 & 67.06 \\
$2.1 \% \mathrm{H}_{2} \mathrm{O}$ addition & 80.69 & 85.01 & 67.27 \\
\hline p-value & 0.001 & 0.001 & 0.430 \\
\hline & & Particle Size & 70.06 \\
\hline Coarse & 76.29 & 77.56 & 66.36 \\
Medium & 76.75 & 83.66 & 0.004 \\
\hline p-value & 0.331 & 0.001 & \\
\hline
\end{tabular}

Heat Treatment

$\begin{array}{llll}\text { Expanded-Pelleted } & 87.08 & 89.47 & 66.42\end{array}$

$\begin{array}{llll}\text { Pelleted } & 65.96 & 71.75 & 70.00\end{array}$ 
p-value

0.001

0.001

0.005

Interactions

MA x PS

p-value

$<0.001$

$<0.001$

$<0.001$

MA x HT

$\mathrm{p}$-value

$<0.001$

$<0.002$

$<0.001$

HT x PS

$\mathrm{p}$-value

$<0.001$

$<0.001$

$<0.389$

SEM

2.64

1.51

7.68

In general, the moisture addition improved the pellet quality. The PDI rose linearly $(\mathrm{P}<0.001)$ with increasing moisture addition in the conditioner. The protein solubility $(\mathrm{KOH})$ of mash feed samples collected before heat treatment and of soybean meal used in this experiment had average values of $73.76 \%$ and $81.92 \%$ respectively. (Table 2 and Table 3 ).
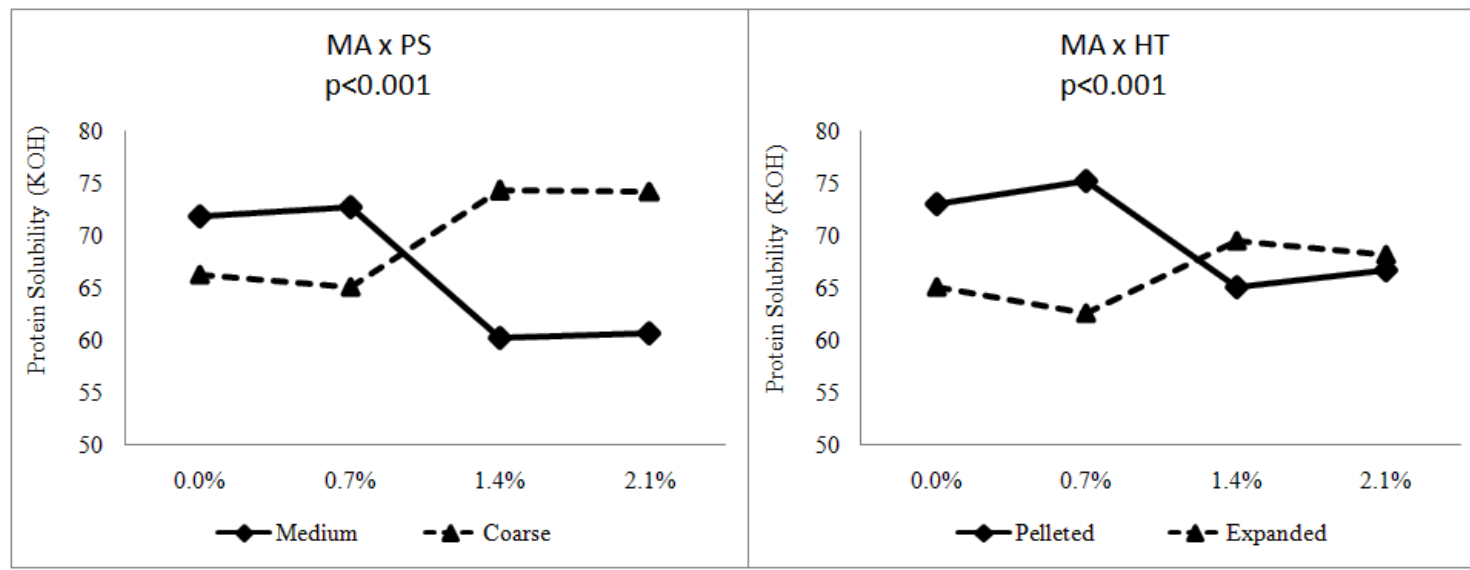

Figure 1. Interaction effects of heat treatment (HT), particle size (PS) and moisture addition (MA) on protein solubility in $\mathrm{KOH}$

The same response was observed for pellet percentage, where different moisture addition levels linearly improved the pellet conversion $(\mathrm{P}<0.001)$ (Table 2 and Table 3$)$.

Expanding-pelleting resulted in better pellet percentage and PDI than just pelleting the mash $(\mathrm{P}<0.001)$, independent of the particle size.

Protein solubility of the diets decreased in pelleted feeds and with medium particle size as the 
moisture addition rose from $0.0 \%$ and $0.7 \%$ to $1.4 \%$ and $2.1 \%$ (Table 2 and Figure 1). The opposite response was observed in expanded-pelleted samples and in coarse particle size samples, where the protein solubility rose when moisture addition went from $0.0 \%$ and $0.7 \%$ to $1.4 \%$ and $2.1 \%$.

Although the effect of moisture on pellet quality was more evident in the samples with coarse grinding and in single pelleted feeds, there was a linear and positive response of water addition on PDI and pellet percentage. Similar results were found by Jiménez-Moreno et al. (2016), who tested respective additions of $2.5 \%$ and $5.0 \%$ and $2.0 \%$ and $4.0 \%$ water in the mixer and observed a positive effect on pellet quality.

The greater effect of moisture addition in single pelleted feeds might be explained by the fact the annular gap expander can homogenize more water in mash feed after conditioning. In general, the conditioner-expander system can add around $1.0 \%$ additional water as steam to the feed prior to the pellet press when compared to normal conditioning. In this experiment, the moisture measurements of samples collected just after the pellet press (prior to cooling) showed that the moisture content of conditioned-expanded feed was on average $0.5 \%$ higher than single conditioned feed. Probably that is the reason for the smoother response slope of pellet quality to the moisture addition in the conditioned-expanded feed.

Coarser particle size impaired protein solubility regarding medium particle size $(\mathrm{p}<0.004$ respectively) (Table 2).

Table 3. Regression equation for pellet durability index (PDI) and pellet conversion percentage considering the following factors: heat treatment (HT), particle size (PS) and moisture addition (MA) and their interactions

\begin{tabular}{lcc}
\hline Equation & $\mathrm{P}$ & R-Square \\
\hline $\mathrm{PDI}=71.179-1.867 * \mathrm{PS}+11.889 * \mathrm{HT}+5.089 * \mathrm{MA}+<0.001$ & 97.9 \\
$0.771 * \mathrm{PS} \mathrm{HT}+1.557 * \mathrm{PS} \mathrm{MA}-1.267 * \mathrm{HT} * \mathrm{MA}$ & & \\
\hline$\%$ Pellets $=76.486-4.4789479 * \mathrm{PS}+10.242 * \mathrm{HT}+3.930 * \mathrm{MA}+$ & $<0.001$ & 94.9 \\
$2.605 * \mathrm{PS} \mathrm{HT}+1.361 * \mathrm{PS} \mathrm{MA}-1.316 * \mathrm{HT} \mathrm{MA}$ & & \\
\hline $\begin{array}{l}\text { Protein solubility in } \mathrm{KOH}=68.752-4.539 * \mathrm{OS}-5.629 * \mathrm{HT} \\
-0.713 * \mathrm{MA}+0.5728 * \mathrm{OS} * \mathrm{HT}+5.889 * \mathrm{PS} \mathrm{MA}+3.460 * \mathrm{HT} * \mathrm{MA}\end{array}$ & \\
\hline
\end{tabular}

Again, significant interactions between the processing procedures were observed. Pellet percentage response to moisture addition was higher in pelleted than expanded-pelleted feeds (16\% x $7 \%$ improvement), and in coarse than medium particle size feeds (15\% x $7 \%$ ). There was an interaction between particle size and heat treatment, since the negative effect of coarser particle size on PDI and pellet percentage was significant only in pelleted feeds.

The addition, of moisture had a more pronounced effect on coarse ground ingredients than on fine ground ingredients. One of the reasons for this response may be the fact that as particle 
size increases, the weaker the bonds between the particles become. The capillary property of water helps to keep the particles bound together (Thomas \& Poel, 1996). Another possible explanation is that with zero water addition, the coarse ground samples had significantly lower pellet quality, and as a consequence a higher possibility of improvement.

The reduction of the particle size in this study resulted in better pellet quality, as also reported by Castellano et al. (2015). The medium particle size (656 microns) resulted in a higher PDI compared to coarse grinding (988 microns). This finding is in accordance with Pacheco-Dominguez (2014), who found that in corn-soybean meal feed for broilers, the ideal particle size is around 650-700 microns. This positive effect of fine grinding on pellet quality was observed only in pelleted samples. The size and shape of the particles influence the nutritional quality of feeds, since they are physical characteristics resulting from different treatment responses (Melo et al. 2016; Domingues et al. 2014).

Protein solubility was decreased by coarser particles in expanded-pelleted feeds but not in pelleted samples (Table 4 and Figure 2).

Table 4. Interaction effects between heat treatment (HT), particle size (PS) and moisture addition (MA) on pellet durability index, pellet percentage and protein solubility (KOH)

\begin{tabular}{|c|c|c|c|c|c|c|}
\hline \multirow{2}{*}{$\begin{array}{l}\text { Factors } \\
\text { MA x HT }\end{array}$} & \multicolumn{2}{|c|}{ Pellet durability index } & \multicolumn{2}{|c|}{ Pellet percentage } & \multicolumn{2}{|c|}{ Protein solubility $(\mathrm{KOH})$} \\
\hline & Pelleted & Expanded & Pelleted & Expanded & Pelleted & Expanded \\
\hline $0.0 \% \mathrm{H}_{2} \mathrm{O}$ add. $*$ & $56.49 \mathrm{~b}$ A & $82.20 \mathrm{a} \mathrm{A}$ & $67.43 \mathrm{a} \mathrm{A}$ & $86.36 \mathrm{~b} \mathrm{~A}$ & $73.07 \mathrm{a} \mathrm{A}$ & $65.13 \mathrm{~b} \mathrm{~A}$ \\
\hline $0.7 \% \mathrm{H}_{2} \mathrm{O}$ add. $*$ & $67.94 \mathrm{~b} \mathrm{~B}$ & 86.50 a B & $68.13 \mathrm{a} \mathrm{A}$ & 89.08 b B & 75.19 a A & 62.58 a A \\
\hline $1.4 \% \mathrm{H}_{2} \mathrm{O}$ add. $*$ & $68.16 \mathrm{~b} \mathrm{~B}$ & 89.51 a C & 73.29 a B & 90.47 b B & 64.99 a B & 69.48 b B \\
\hline $2.1 \% \mathrm{H}_{2} \mathrm{O}$ add. $*$ & 71.26 b C & 90.12 a C & 78.03 a C & 91.99 a C & 66.73 a B & 68.18 b B \\
\hline p-value & \multicolumn{2}{|c|}{0.000} & \multicolumn{2}{|c|}{0.000} & \multicolumn{2}{|c|}{0.000} \\
\hline MA $x$ PS & Medium & Coarse & Medium & Coarse & Medium & Coarse \\
\hline $0.0 \% \mathrm{H}_{2} \mathrm{O}$ add. $*$ & 71.98 a A & $66.72 \mathrm{~b} \mathrm{~A}$ & 80.94 a A & $72.85 \mathrm{~b} \mathrm{~A}$ & $71.92 \mathrm{a} \mathrm{A}$ & $66.28 \mathrm{~b} \mathrm{~A}$ \\
\hline $0.7 \% \mathrm{H}_{2} \mathrm{O}$ add. $*$ & 77.28 a B & 77.17 a B & 82.78 a B & 74.43 b B & 72.66 a B & $65.11 \mathrm{~b} \mathrm{~A}$ \\
\hline $1.4 \% \mathrm{H}_{2} \mathrm{O}$ add. $*$ & 77.69 a B & 79.98 b C & 84.31 a B & $79.45 \mathrm{~b} \mathrm{C}$ & 60.17 a C & $74.31 \mathrm{~b} \mathrm{~B}$ \\
\hline $2.1 \% \mathrm{H}_{2} \mathrm{O}$ add. $*$ & 80.07 a C & 81.30 a D & 86.50 a C & $83.52 \mathrm{~b} \mathrm{D}$ & 60.68 a C & $74.23 \mathrm{~b} \mathrm{~B}$ \\
\hline p-value & \multicolumn{2}{|c|}{0.000} & \multicolumn{2}{|c|}{0.000} & \multicolumn{2}{|c|}{0.000} \\
\hline HT x PS & Medium & Coarse & Medium & Coarse & Medium & Coarse \\
\hline
\end{tabular}




\begin{tabular}{|c|c|c|c|c|c|c|}
\hline Pelleted & 66.97 a A & $64.96 \mathrm{~b} \mathrm{~A}$ & $77.34 \mathrm{a} \mathrm{A}$ & $66.10 \mathrm{~b} \mathrm{~A}$ & 68.93 a A & $71.07 \mathrm{a} \mathrm{A}$ \\
\hline Expand.-Pel.** & 86.54 a B & 87.62 a B & 89.92 a B & 89.03 a B & 63.79 a B & $68.89 \mathrm{~b} \mathrm{~A}$ \\
\hline p-value & \multicolumn{2}{|c|}{0.000} & \multicolumn{2}{|c|}{0.000} & \multicolumn{2}{|c|}{0.033} \\
\hline SEM & \multicolumn{2}{|c|}{1.04} & \multicolumn{2}{|c|}{0.93} & \multicolumn{2}{|c|}{0.72} \\
\hline
\end{tabular}

*add.: addition ** Expanded - Pelleted

In expanded-pelleted feeds, the different particle sizes did not affect the PDI or the pellet percentage. Probably the changes in feed texture by the temperature, pressure and moisture of the annular gap expander overwhelmed the breaking forces of the bigger particles present in coarse grinding

Calculation of the binding strength between solids by Laplace's equation (binding strength = $2 \mathrm{x}$ (liquid surface tension / particle diameter / 2) revealed why particle size has a strong impact on the bonds inside the pellets (Thomas \& Poel, 1996).

The pellet conversion percentage and PDI were respectively $18 \%$ and $21 \%$ higher for expanded-pelleted compared to pelleted feed samples. These results are in accordance with Fancher et al. (1996), who reported a survey of North American feed mills where the annular gap expander increased the PDI values of chicken feed from 15 to $25 \%$ compared to a simple conditioning process.

We observed that pelleted feed had higher $(\mathrm{p}<0.005)$ protein solubility in $\mathrm{KOH}$ when compared to expanded-pelleted feed (70.0\% x 64.2\%). Muramatsu et al. (2013) also observed that expanding soybean meal at $130-136{ }^{\circ} \mathrm{C}$ decreased protein solubility in $\mathrm{KOH}$ from $80.57 \%$ to $64.12 \%$. However, Lima et al. (2016) observed that the thermal processing provided better availability of the protein from the hydrolysis of the starch present in the tested feeds.

Interactions between the different processing factors were significant. Moisture addition was more effective in increasing the PDI values in pelleted than in expanded-pelleted samples (26\% x $10 \%$ improvement) and in coarse than medium particle size samples (22\% x 11\%). 


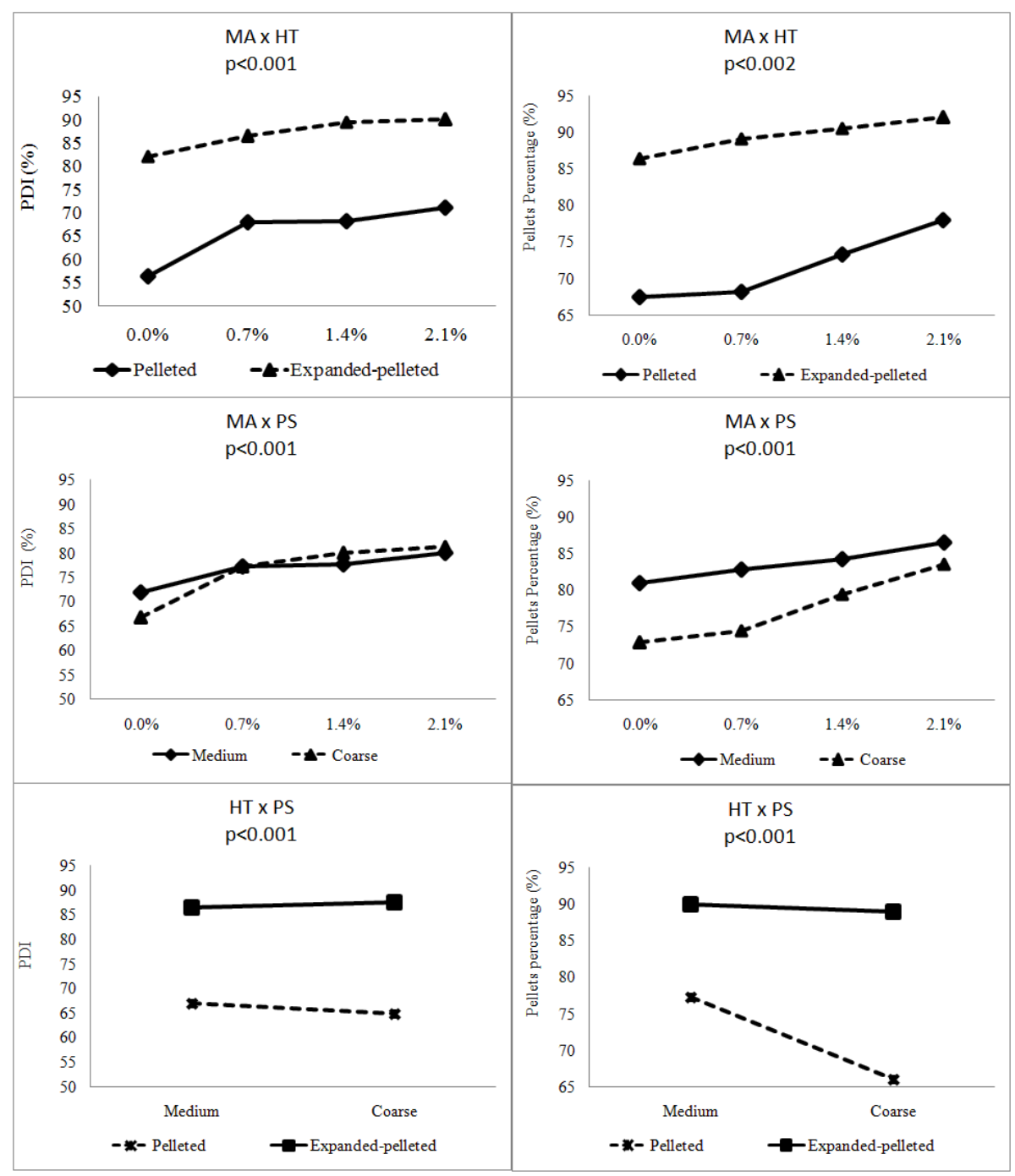

Figure 2. Effect of heat treatment (HT), particle size (PS) and moisture addition (MA) on pellet durability index and pellet percentage

\section{Conclusion}

Adding moisture in the conditioner up to $2.1 \%$ enhanced the pellet quality of the feeds. The addition of moisture proved important mainly with coarse grinding. In the same way, the use of the annular gap expander proved to be a beneficial thermal feed process if the aim is to increase pellet percentage and PDI. The improvements in PDI and \% pellets reached, respectively, $18 \%$ and $21 \%$ in the present study and had an effect on protein quality when higher processing temperature was used.

\section{References}

American Society of Agricultural and Biological Engineers (ASABE). (2006). Method ofDetermining and Expressing Fineness of Feed Materials by Sieving. American National Standard Institute S319.3 Feb. 03. ASABE Standards.

Association of Official Analytical Chemists International (AOAC). (1998). Method 90.15 in 
Official Methods of Analysis. 16th ed. AOAC, Arlington, VA.

Attar, A., Kermanshahi, H., \& Golian, A. (2017). Efeitos do tempo de condicionamento e bentonite de sódio na qualidade dos grânulos, desempenho de crescimento, morfologia intestinal e retenção de nutrientes em frangos de corte finalizadores. Ciência da avicultura britânica.

Boemo, L. S., Rosa, D. P., Rosa, A. P., Orso, C., Schier, A., Genhrke, S. B., Silva, A. E., \& Mariani, A. B. (2016). Thermal processes in diets for broiler in the pre-starter phase. Revista Brasileira de Saúde e Produção Animal, 17, 195-201. https://doi.org/10.1590/S1519-99402016000200007

Castellano, J. M., Gómez, M., Fernández, M., Esteban, L. S., \& Carrasco, J. E. (2015). Estudo sobre os efeitos da composição das matérias-primas e condições de granulação sobre a qualidade e propriedades dos grânulos obtidos a partir de diferentes biomassas lenhosas e não arborizadas. Fuel, 139, 629-636. https://doi.org/10.1016/j.fuel.2014.09.033

Domingues, C. H. F., Andrade,. P C., Sgavioli, S., Praes, M. F. F. M., Duarte, K. F., Petrolli, T. G., \& Junqueira, O. M. (2014). Efeito da forma física da ração sobre o desempenho de frangos de corte. Revista Agrocientífica, 1, 51-60.

Fancher, B. I., Rollins, D., \& Trimbe, B. (1996). Feed processing using the annular gap expander and its impact on poultry performance. Journal of Applied Poultry Research, 5, 386-394. https://doi.org/10.1093/japr/5.4.386

Franke, M., \& Rey, A. (2006). Improving pellet quality and efficiency. Feed Technology, 10, 3.

Jiménez-Moreno, E., de Coca-Sinova, A., González-Alvarado, J. M., \& Mateos, G. G. (2016). Inclusão de fontes de fibras insolúveis em dietas de purê ou pellets para frangos de corte jovens. 1. Efeitos no desempenho do crescimento e na ingestão de água. Ciência da Avicultura, 95(1), 41-52.

Lima, M. F., Couto, H. P., Corte, R. G. S. C. P., Soares, R. T. R. N., Gomes, A. V. C., \& Curvello, F. A. (2016). Energy values of expander feed in different temperatures for broilers. Arquivo Brasileiro de Medicina Veterinária e Zootecnia, 68, 725-732. https://doi.org/10.1590/1678-4162-7866

Melo, A. S., Queiroz, J. P. A. F., Oliveira, V. R. M., Dias, F. K. D., Fernandes, R. T. V., Marinho, J. B. M, Souza RF, Filho, C.A.S., Souza, A.O.V \& Arruda, A.M.V. (2016). Formas físicas de utilização de rações para aves. Pubvet, 10, 173-178. https://doi.org/10.22256/pubvet.v10n2.173-178

Mendez, J., Rial, E., \& Santomá, G. (2008). Feed Manufacturing. The Nutrition of the Rabbit. Cab International.

Mina-boac, J., Maghirang, R. G., \& Casada, M. E. (2006). Durability and Breakage of Feed Pellets during Repeated Elevator Handling. Material escrito para a palestra na ASABE 
Annual International Meeting. ASABE. Portland, Oregon. 9-12.

Muramatsu, K., Maiorka, A., Vaccari, I. C. M., Reis, R. N., Dahlke, F., Pinto, A. A., \& Imagawa, M. (2013). Impact of particle size, thermal processing, fat inclusion and moisture addition on pellet quality and protein solubility of broiler feeds. Journal of Agricultural Science and Technology. A, 3(12A), 1017.

Parsons, C. M., Hashimoto, K., Wedekind, K. J., \& Baker, D. H. (1991). Soybean protein solubility in potassium hydroxide: an in vitro test of in vivo protein quality. Journal of Animal Science, 69, 2918-2924. https://doi.org/10.2527/1991.6972918x

Rhuhnke, I., Knorr, F., Mader, A., Boroojeni, F. G., Löwe, R., \& Zentek, J. (2014). Effects of grinding method, particle size, and physical form of the diet on gastrointestinal morphology and jejunal glucose transport in laying hens. Poultry Science, 93, 2060-2068. https://doi.org/10.3382/ps.2013-03783

Röhe, Prestlokken, E., \& Forutvikling, F. (2012). Expander treatment. HFE 305 Feed Manufacturing Technology.

Thomas, M., Van der Poel \& A. F. B. (1996). Physical quality of pelleted animal feed. 1. Criteria for pellet quality. Animal Feed Science Technology, 61. https://doi.org/10.1016/0377-8401(96)00949-2

Thomas, M., Viliet, T., Van der Poel \& A.F.B. (1998). Physical quality of pelleted animal feed. 3. Contribution of feedstuff components. Animal Feed Science Technology, 70. https://doi.org/10.1016/S0377-8401(97)00072-2

Vukmirović, Đ., Čolović, R., Rakita, S., Brlek, T., Đuragić, O., \& Solà-Oriol, D. (2017). Importância da estrutura de alimentação (tamanho de partícula) e forma de alimentação (mash vs pellets) na nutrição de porco - Uma revisão. Animal Feed Science and Technology.

\section{Copyright Disclaimer}

Copyright for this article is retained by the author(s), with first publication rights granted to the journal.

This is an open-access article distributed under the terms and conditions of the Creative Commons Attribution license (http://creativecommons.org/licenses/by/4.0/). 